\title{
Isolated unilateral ptosis as a presenting feature of midbrain infarction
}

\author{
Banshi Lal Kumawat, Maulik Panchal, Deepika Sagar
}

Department of Neurology, Sawai Mansingh Medical College and Hospital, Jaipur, India

Correspondence to Dr Banshi Lal Kumawat, kumawatbl04@gmail.com

Accepted 10 January 2018
Check for updates

To cite: Kumawat $\mathrm{BL}$, Panchal M, Sagar D. BMJ Case Rep Published Online First: [please include Day Month Year]. doi:10.1136/ bcr-2017-223750

\section{DESCRIPTION}

A 60-year-old female patient, non-smoker, with known case of coronary artery disease (CAD) but treatment defaulter, presented to us with complaints of sudden-onset vertigo followed by drooping of the left eyelid without any diurnal fluctuation for the last 3 days. There was no history of headache, double vision or any other complaints. On examination she had normal blood pressure. Neurological examination revealed partial unilateral ptosis of the left side without pupillary involvement or restriction of ocular movements; the rest of the neurological examination was normal. She did not have any other clinical signs or symptoms suggestive of Horner's syndrome, such as miosis or hemifacial anhidrosis. Prism cover test was performed, which did not show latent or manifest deviation of either eye. As patient had sudden onset of painless ptosis with risk factors of stroke such as age and CAD (off treatment), diagnosis of cerebrovascular accident was suspected. MRI of the brain with diffusion-weighted image (figure 1A) was done, which showed diffusion restriction with corresponding fall in apparent diffusion coefficient (figure 1B) in the left paramedian midbrain region suggestive of acute infarct. We did not

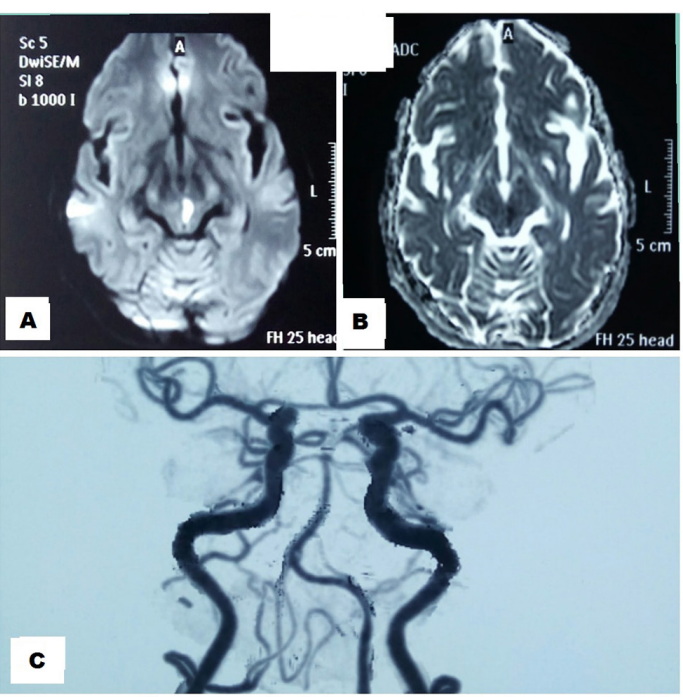

Figure 1 (A) MRI of the brain with diffusion-weighted image shows diffusion restriction in the left paramedian midbrain region with corresponding fall in apparent diffusion coefficient (B). (C) CT angiography image of the brain vessels suggestive of hypoplastic right vertebral artery.

\section{Learning points}

- Although acute or sudden-onset, isolated unilateral ptosis has many differentials, painless ptosis in an elderly patient with vascular risk factors should make us think about the possibility of midbrain infarct, and MRI brain with diffusion-weighted image should be done urgently.

- Lacunar midbrain infarction may have varied neuro-ophthalmological presentations, including unilateral ptosis with mono-ocular elevation palsy, or bilateral ptosis with extraocular muscle weakness. Midbrain infarction with infarction of the structures supplied by posterior circulation is more common than isolated midbrain infarction. Isolated unilateral ptosis in our case could be due to selective involvement of midbrain oculomotor nerve fascicle supplying the levator palpebral superioris. Oculomotor nerve fascicles to pupillary, extraocular and eyelid elevation muscles are such compactly and topographically arranged within a small area that selective involvement of only levator palpebral superioris fascicle is very rare in itself.

suspect posterior communicating artery (Pcom) aneurysm as a cause of ptosis as she had painless ptosis without extraocular muscle weakness or pupillary involvement. However, CT angiography of the brain vessels was done as part of stroke work-up and to rule out remote possibility of Pcom artery aneurysm. CT angiography of the brain vessels showed hypoplastic right vertebral artery (figure 1C). It is difficult to say whether it was the responsible factor for stroke or not, but several studies have found association of posterior circulation stroke with hypoplastic vertebral artery. The rest of the work-up for stroke was done, and investigations including lipid profile and random blood sugar were normal; ECG showed T wave inversion in V1-V4 leads. Two dimensional echo was unremarkable. She was managed conservatively with antiplatelet and management of CAD. She started showing improvement of ptosis from the second day of admission. In literature, cases of unilateral or bilateral ptosis with or without extraocular muscles involvement in case of midbrain infarction have been described rarely which is explained by selective oculomotor nerve fascicles lesions. ${ }^{12}$ 
Contributors BLK contributed to manuscript concept and design, while MP and DS performed manuscript writing, editing and literature searching.

Funding This research received no specific grant from any funding agency in the public, commercial or not-for-profit sectors.

Competing interests None declared.

Patient consent Obtained.

Provenance and peer review Not commissioned; externally peer reviewed.
(C) BMJ Publishing Group Ltd (unless otherwise stated in the text of the article) 2018. All rights reserved. No commercial use is permitted unless otherwise expressly granted.

\section{REFERENCES}

1 Sugawara E, Nakamura $\mathrm{H}$, Endo M, et al. Isolated Unilateral Ptosis due to Paramedian Midbrain Infarction. I Stroke Cerebrovasc Dis 2015;24:e121-e123.

2 Choi YJ, Lee SH, Park MS, et al. Midbrain infarction presenting with monocular elevation palsy and ptosis: topographic lesion analysis. J Neuroophthalmol $2015 \cdot 35 \cdot 175-8$

Copyright 2018 BMJ Publishing Group. All rights reserved. For permission to reuse any of this content visit

http://group.bmj.com/group/rights-licensing/permissions.

BMJ Case Report Fellows may re-use this article for personal use and teaching without any further permission.

Become a Fellow of BMJ Case Reports today and you can:

- Submit as many cases as you like

- Enjoy fast sympathetic peer review and rapid publication of accepted articles

- Access all the published articles

Re-use any of the published material for personal use and teaching without further permission

For information on Institutional Fellowships contact consortiasales@bmjgroup.com

Visit casereports.bmj.com for more articles like this and to become a Fellow 